\title{
New Catalyst for HER and CO2 Hydrogenation for Solar Fuel Production
}

\section{Chorkendorff, Ib}

\section{Published in:}

Electrochemical Society. Meeting Abstracts (Online)

Publication date:

2013

\section{Document Version}

Publisher's PDF, also known as Version of record

Link back to DTU Orbit

Citation (APA):

Chorkendorff, I. (2013). New Catalyst for HER and CO Hydrogenation for Solar Fuel Production. Electrochemical Society. Meeting Abstracts (Online), NAA2013-01, 20584.

\section{General rights}

Copyright and moral rights for the publications made accessible in the public portal are retained by the authors and/or other copyright owners and it is a condition of accessing publications that users recognise and abide by the legal requirements associated with these rights.

- Users may download and print one copy of any publication from the public portal for the purpose of private study or research.

- You may not further distribute the material or use it for any profit-making activity or commercial gain

- You may freely distribute the URL identifying the publication in the public portal

If you believe that this document breaches copyright please contact us providing details, and we will remove access to the work immediately and investigate your claim. 


\title{
New Catalyst for HER and $\mathrm{CO}_{2} \mathrm{Hydrogenation} \mathrm{for} \mathrm{Solar} \mathrm{Fuel} \mathrm{Production}$
}

\author{
Ib Chorkendorff \\ Department of Physics, Technical University of Denmark
}

Hydrogen is the simplest solar fuel to produce and while platinum and other noble metals are efficient catalysts for photoelectrochemical hydrogen evolution, earth-abundant alternatives are needed for largescale use. We have shown that bio-inspired molecular clusters based on transition metal sulfides mimics nature's enzymes for hydrogen evolution when deposited on various supports $[1,2]$. When these catalysts are deposited on p-type Si they can harvest the red part of the solar spectrum and potentially be coupled to $\mathrm{CO} 2$ hydrogenation [3-5]. Such a system could constitute the cathode part of a tandem dream device where the red part of the spectrum is utilized for solar fuel evolution, while the blue part is reserved for the more difficult oxygen evolution. Recently we have found that this system can be improved considerably using a np-Si systems [6] as recently described by the Nate Lewis group [7]. Hereby it is possible to achieve photoelectrochemical $\mathrm{H}_{2}$ production at $+0.33 \mathrm{~V}$ vs. RHE using a porous, amorphous $\mathrm{MoS}_{\mathrm{x}}$ catalyst. To stabilize Si during catalyst deposition and the subsequent hydrogen evolution reaction (HER), a corrosion protective layer is shown to be indispensable. At $200 \mathrm{mV}$ positive of RHE the cell produce an incident photon to current efficiency (IPCE) of 50\%. This work represents a substantial reduction in $\mathrm{H}_{2}$ evolution overpotential for non-Pt Si-photocathode operated in acidic solution. Further improvement in corrosion protection using several $100 \mathrm{~nm}$ of $\mathrm{TiO}_{2}$ [8] will be demonstrated and coupling to $\mathrm{CO}_{2}$ hydrogenation will discussed if time allows.

1. B. Hinnemann et al., Biomimetic hydrogen evolution: $\operatorname{MoS}(2)$ nanoparticles as catalyst for hydrogen evolution. Journal of the American Chemical Society 127, (2005) 5308.

2. T. F. Jaramillo et al., Identification of active edge sites for electrochemical H-2 evolution from MoS2 nanocatalysts. Science 317, (2007) 100.

3. Y. Hou et al., Bioinspired molecular co-catalysts bonded to a silicon photocathode for solar hydrogen evolution. Nature Materials 10, (2011) 434.

4. A. B. Laursen, S. Kegnæs, S. Dahl, and I. Chorkendorff, "Molybdenum sulphides - effecient and viable materials for electro- and photoelectrocatalytic hydrogen evolution" Energy \& Environ. Sci., (2012) DOI: 10.1039/C2EE02618J

5. W. Tang, A. A. Peterson, A. S. Varela, Z. Jovanov, L. Bech, W. J. Durand, S. Dahl, J. K. Nørskov, I. Chorkendorff "The Importance of Surface Morphology in Controlling the Selectivity of Polycrystalline Copper for CO2 Electro reduction", PCCP 14 (2012) 76-81.

6. B. Seger, A. B. Laursen, P.C.K. Vesborg, T. Pedersen, O. Hansen, S. Dahl, and I. Chorkendorff, "Hydrogen Production from a Molybedum Sulfide Catalyst on protected np -Silicon Photocathode." Angew. Chem. Int. Ed., 51 (2012) 9128-9131.

7. S. W. Boettcher, E. L. Warren, M. C. Putnam, E. A. Santori, D. Turner-Evans, M. D. Kelzenberg, M. G. Walter, J. R. McKone, B. S. Brunschwig, H. A. Atwater, et al., JACS 133 (2011) 1216-9.

8. B. Seger, A. B. Laursen, T. Pedersen, P. C.K. Vesborg, O. Hansen, and I. Chorkendorff, ” Using TiO2 as a Conductive Protective Layer for Photocathodic H2 evolution", Submitted (2012). 